Rev. Biol. Trop. 52(1): 133-138, 2004

www.ucr.ac.cr www.ots.ac.cr www.ots.duke.edu

\title{
The reserpine effects on the gonadotrophic cells of the male common carp Cyprinus carpio (Osteichtyes: Cyprinidae)
}

\author{
Lilian González-Segura \& Rodolfo Cárdenas-Reygadas \\ Laboratorio 2, Unidad de Morfología y Función. Facultad de Estudios Superiores Iztacala. Universidad Nacional Autónoma \\ de México. Av. de los Barrios No 1, Los Reyes Iztacala, Tlalnepantla, Edo. de México, C.P. 54090, Apdo. Postal 314, \\ Tlal., México. Tel.: (52) (55) 5623-1151, (52) (55) 5623-1253. Fax: (52) (55) 5623-1155; rodolf@ servidor.unam.mx
}

Received 02-II-2001. C Corrected 12-IX-2001. Accepted 08-I-2002.

\begin{abstract}
The secretion of gonadotropins $(\mathrm{GtH})$ in goldfish and carp, is stimulated by GtH-releasing hormone $(\mathrm{GnRH})$ and is inhibited by dopamine. Studies with antidopaminergics have demonstrated to be effective in order to stimulate the spermiation and the ovulation in different species of teleosts. The reserpine, a drug that deplets the dopamine, has shown to stimulate the spermiation in the common carp. We report here, the effects of reserpine on the number and volume of gonadotrophic cells of the common carp. Eight injections of reserpine alone, at doses of $0.5,1.0$ or $1.5 \mathrm{mg} / \mathrm{ml} / \mathrm{kg}$ of body weight and at intervals of 48 hours, caused an increase in the number and volume of gonadotrophic cells. The dose $0.5 \mathrm{mg} / \mathrm{ml} / \mathrm{kg}$, presented an increase in the number and volume of gonadotrophic cells of $382 \%$ and $123 \%$, respectively, above the control group. The dose 1.0 $\mathrm{mg} / \mathrm{ml} / \mathrm{kg}$, showed an enhanced number and volume of gonadotrophic cells of $704 \%$ and $152 \%$, respectively. With the dose $1.5 \mathrm{mg} / \mathrm{ml} / \mathrm{kg}$ increase in number $(171 \%)$ and volume $(106 \%)$ of gonadotrophic cells was lower. The gonads of the experimental groups had an abundance of advanced states of spermatogenesis. Our results show that eight intraperitoneal injections of reserpine were responsible for an increase in gonadodrophic cell, number and volume.
\end{abstract}

Key words: Reserpine, gonadotrophic cells, goldfish, pituitary, dopamine.

It has been established that secretion of gonadotropin $(\mathrm{GtH})$ in goldfish (Chang and Peter 1983) and carp (Sokolowska et al. 1988), is stimulated by GtH-releasing hormone $(\mathrm{GnRH})$ and is inhibited by dopamine, throughout mechanisms which involve $\mathrm{D}_{2}$ receptors (Chang et al. 1993). Intraperitoneal injections of dopamine antagonists potentiated the $\mathrm{GtH}$ release response and increased the frequency of ovulation or spermiation, induced in goldfish (Chang and Peter 1983, Chang et al. 1984a, Sokolowska et al. 1985), common carp (Billard et al. 1983) and silver carp (Lin et al. 1985).

Reserpine is a substance which depletes catecholamines stores, thus potentiating the effects of LHRH-A on serum gonadotropin levels, ovulation and spermiation, in common carp (Sokolowska et al. 1988) and in loach (Lin et al. 1986, Sokolowska et al. 1988). Reserpine has been shown to be able to induce, in vivo, an increase in GtH levels, 48 hours postinjection in mature carps (Sokolowska et al. 1988).

In order to understand the influence of this antidopaminergic, we investigated the effects of three different doses of reserpine, on gonadotrophic cells, in the pituitary gland of male carps.

\section{MATERIALS AND METHODS}

Male common carps, Cyprinus carpio L., variety koi, (200 \pm 10 g body weight) were 
purchased from local dealers. Upon arrival, animals were maintained for three weeks in 3001 tanks, at $19^{\circ} \mathrm{C} \pm 1^{\circ} \mathrm{C}$ and under a photoperiod of $12 \mathrm{~L} / 12 \mathrm{D}$. The experiment was carried out in February.

A total of 30 male carps were divided into 6 groups of 5 individuals each:

Group 1: Fish were sacrificed at the start of the experiment. The gonads and pituitaries were rapidly removed in order to evaluate their initial status.

Group 2: Untreated fish.

Group 3: The fish were injected intraperitoneally (ip) with vehicle propylene glycol and dimethyl sulfoxide (DMSO) (9:1)), with a dose of $1 \mathrm{ml} / \mathrm{kg}$ body weight, in 8 injections at intervals of 48 hours.

Groups 4, 5 and 6: The fish were injected intraperitoneally with reserpine (Lot \# 58f0346, Sigma, Co. St. Louis, MO, USA.). at doses of $0.5,1.0$ and $1.5 \mathrm{mg} / \mathrm{ml} / \mathrm{kg}$ of body weight. In 8 injections at intervals of 48 hours respectively.

The injections were applied between 9:00 and 11:00 hours. The fish from groups 2, 3, 4, 5 and 6 were killed by decapitation $48 \mathrm{~h}$ after the last injection. Just before they were sacrificed, the fish were weighed. The testes and pituitaries were rapidly removed. The gonad weight expressed as a percentage of fish somatic weight (Sturm 1978) was used as gonado-somatic index (GSI). The testes were fixed in formaline in phosphate buffer $4 \% \mathrm{pH}$ 7.2 for 24 hours, washed in tap water, dehydrated in a graded series of ethanol and embedded in paraffin. Sections of $3 \mu \mathrm{m}$ thick were stained with Hematoxilin-Eosin and mounted with synthetic resin (Luna 1968). The sections were examined on a Carl Zeiss microscope. The evaluation of the gonadal status was based on the predominant cells (primary spermatocytes, secondary spermatocytes or spermatids and sperm).

The pituitaries were fixed in formalinesublimate (mercuric chloride, $5.43 \mathrm{~g}$; formaldehyde, $10 \mathrm{ml}$; distilled water, $90 \mathrm{ml}$ ) for 24 hours. Before the pituitaries were embedded, they were decalcified with $0.1 \mathrm{M}$ ethylendi- aminetetraacetate (EDTA) for 5 hours. Serial paraffin sections of $5 \mu \mathrm{m}$ were obtained in sagital plan and were stained using the combined stain for fish pituitary (Jafri 1979) and mounted with synthetic resin.

All gonadotrophic cells were counted every fifth section and the mean cell number per pituitary was calculated for each gland and each treatment group. The gonadotrophic cell volume was determinated in 60 gonadotrophic cells per fish, using the sphere or ellipse formula, depending of the cellular shape. The mean cell volume was obtained in relationship with the treatment.

The Kruskall Wallis test $(\mathrm{p}<0.05)$ and the MannWhitney U-test ( $\mathrm{p}<0.05)$ (Siegel 1994) were used to compare the number and the size of the gonadotrophic cells between experimental and control groups.

\section{RESULTS}

Injection of reserpine at doses of 0.5 $\mathrm{mg} / \mathrm{kg}$ body weight (group 4) and $1.0 \mathrm{mg} / \mathrm{kg}$ body weight (Group 5) was followed by a significant increase in the number of gonadotrophic cells, compared to the control groups, while the injections of reserpine at the higher doses $(1.5 \mathrm{mg} / \mathrm{kg}$ body weight; Group 6) was followed by a smaller increase in the number of gonadotrophic cells (Fig. 1).

The experimental groups showed an increase in the number of gonadotrophic cells; Group 5 presented a mean of 2506 and Group 4, 1361 cells per gland. These values were significantly above the controls. Group 6 had a mean of 610 cells, there was no difference $(p<0.05)$ between this group and Groups 1 and 2 , but there was a significant difference $(\mathrm{p}<0.05)$ with Group 3 (Table 1). When the number of gonadotrophic cells were expressed as a percentage, Group 2 values were taken as $100 \%$. The experimental Groups 5, 4 and 6 registered $704.99 \%, 382.91 \%$ and $171.64 \%$, respectively.

The effects of the reserpine on the volume of gonadotrophic cells, are shown in Table 1. 


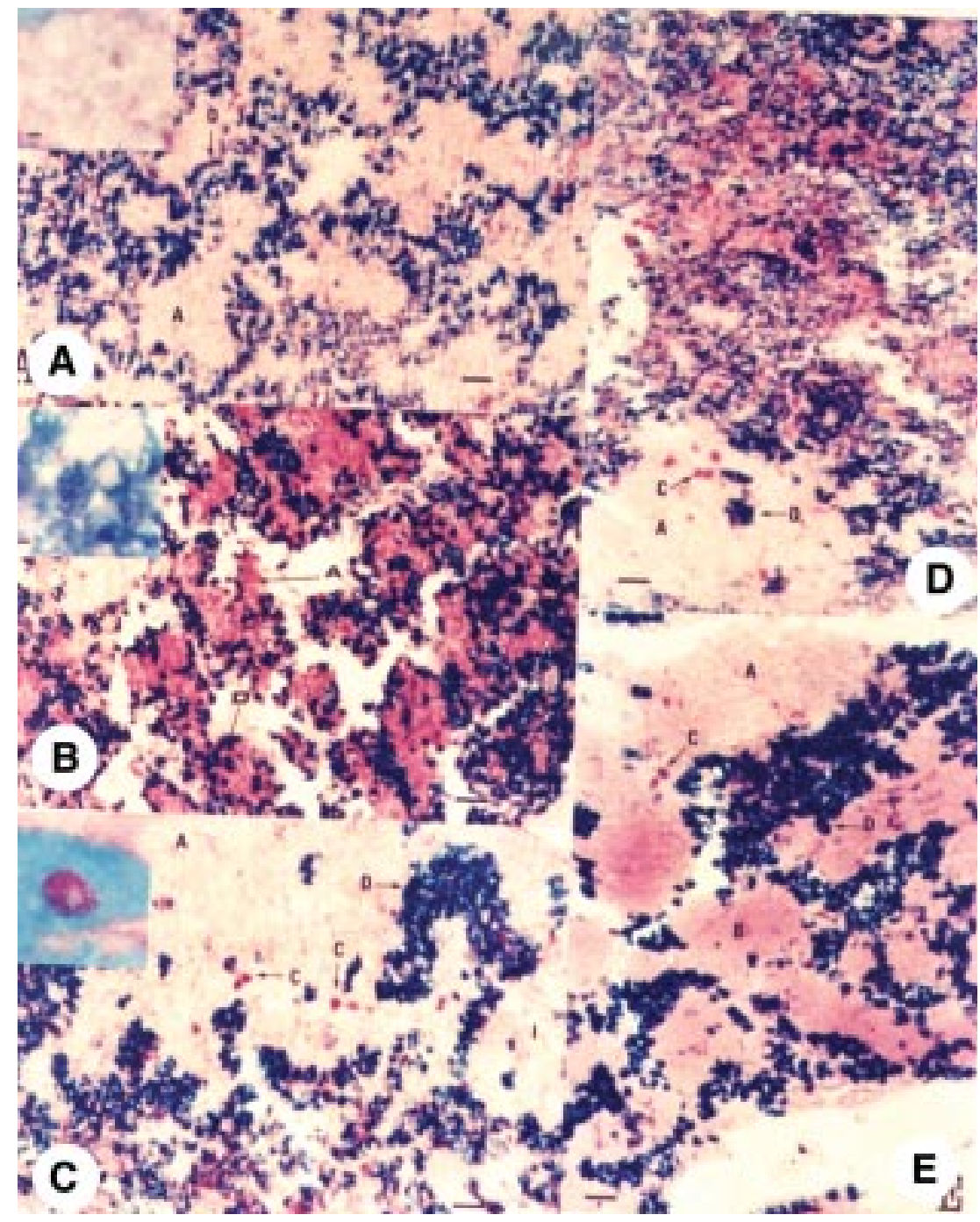

Fig. 1. Gonadotrophic cells in A) Control group. Note the absence of gonadotrophic cells. Inset, corticotrophic cells. Bar scale $5 \mu \mathrm{m}$. B) Group injected with vehicle. Note the absence of gonadotrophic cells. Inset, thyrotrophic cells. Bar scale 5 $\mu \mathrm{m}$. C) Group injected with $0.5 \mathrm{mg}$ of reserpine. Note the presence of gonadotrophic cells. Inset, gonadotrophic cells. Bar scale $5 \mu \mathrm{m}$. D) Group injected with 1.0 of reserpine. Note the presence of gonadotrophic cells. E) Group injected with 1.5 mg of reserpine. Few gonadotrophic cells are noted. (A) Corticotrophic cells; (B) Somatotrophic cells; (C) Gonadotrophic cells; (D) Thyrotrophic cells. Bar scale $25 \mu \mathrm{m}$.

In Groups 4 and 5 injected with reserpine at doses of 0.5 and $1.0 \mathrm{mg} / \mathrm{ml} / \mathrm{kg}$, respectively, cells showed an increase in their volume. The volume of the gonadotrophic cells in Group 4 had a mean of $246.94 \mu \mathrm{m}^{3}$. While Group 5 injected with $1.0 \mathrm{mg} / \mathrm{ml} / \mathrm{kg}$, registered a mean of $304.93 \mu \mathrm{m}^{3}$. These values were higher than the Groups 1, 2, 3 and 6 values (Table 1). Groups 4 and $5(0.5$ and $1.0 \mathrm{mg} / \mathrm{ml} / \mathrm{kg}$, respectively) showed a significant $(\mathrm{p}<0.05)$ increase in the volume of gonadotrophic cells, compared to groups 1, 2 and 3; but there were no differences $(\mathrm{p}<0.05)$ between Group $6(1.5$ $\mathrm{mg} / \mathrm{ml} / \mathrm{kg}$ ) and Groups 1 and 2. 
TABLE 1

Effects of intraperitoneal injection of reserpine on number and volume of gonadotrophic cells and GSI in male common carp Cyprinus carpio

$\begin{array}{lrrr}\text { Group } & \begin{array}{c}\text { Number of } \\ \text { gonadotrophic } \\ \text { cells/pituitary }\end{array} & \begin{array}{c}\text { Volume of } \\ \text { gonadotrophic } \\ \text { cells }\left(\mu \mathrm{m}^{3}\right)\end{array} & \text { GSI } \\ \text { 1. Control } & 220 \pm 6 & 204 \pm 4 & 4.2 \pm 0.3 \\ \text { 2. Control } & 356 \pm 159 & 221 \pm 7 & 4.9 \pm 0.3 \\ \text { 3. Vehicle } & 418 \pm 66 & 189 \pm 14 & 4.5 \pm 0.5 \\ \text { 4. Reserpine (0.5) } & 1361 \pm 219^{*} * * & 247 \pm 18^{*} * * & 4.9 \pm 0.4 \\ \text { 5. Reserpine (1.0) } & 2506 \pm 470^{*} * * & 305 \pm 27 * * * & 5.2 \pm 0.8 \\ \text { 6. Reserpine (1.5) } & 610 \pm 152^{*} & 214 \pm 19 & 4.9 \pm 0.3\end{array}$

Values are mean $\pm \operatorname{SEM}(n=5)$.

Doses in parentheses given in $\mathrm{mg} / \mathrm{ml} / \mathrm{kg}$ body weight; eight intraperitoneal injections were injected. $(*)$ indicates values significantly different from control groups $(\mathrm{p}<0.05)$.

$(* *)$ indicates values significantly different from vehicle $(\mathrm{p}<0.05)$.

The volume of gonadotrophic cells was expressed as a percentage, Group 2 values were taken as $100 \%$. Experimental Groups 4, 5 and 6 , presented $123.11 \%, 152.03 \%$ and $106.84 \%$ respectively. The highest increase in the number and volume of gonadotrophic cells was found in fish injected with $1.0 \mathrm{mg} / \mathrm{ml} / \mathrm{kg}$, compared to other experimental and control groups.

\section{DISCUSSION}

Preview reports have shown that reserpine can induce the $\mathrm{GtH}$ releasing, both in vitro (Chang et al.1983), and in vivo (Sokolowska et al. 1988). In fact, mature carps treated with reserpine at $1.0 \mathrm{mg} / \mathrm{ml} / \mathrm{kg}$ of body weight doses, had better response on $\mathrm{GtH}$ releasing, than other carps treated at $7.0 \mathrm{mg} / \mathrm{ml} / \mathrm{kg}$ of body weight doses, which were measured by GtH serum level, and time period of 48 hours between the injection and maximum serum level.

Clearly, our results show that eight ip injections were responsible for an increase in gonadotrophic cell number and volume, probably causing an enhancement on the GtH synthesis when these cells are free of the dopamine influence for long time periods, due to the reserpin action.
Due to the staining technique used, we could not distinguish more than one type of gonadotrophic cell, this made it impossible to know whether GtH I or GtH II or both were released.

The sections of the testes showed that the control groups had spermatocytes cysts, spermatids and spermatozoa. The experimental Groups 4, 5 and 6 showed only spermatozoa (Fig. 2). On the other hand, the highest GSI were found in Group 5 compared to all the other groups, but there were no differences $(\mathrm{p}<0.05)$ between control and experimental groups (Table 1).

As the reserpine depletes all catecholamins, dopamine has negative effects (Chang et al. 1984a, 1984b, Peter et al. 1986) and norepinephrine has positive effects on $\mathrm{GtH}$ releasing (Chang et al. 1984a,), the long term reserpine injections seem to cause an antidopaminergic action, enhancing $\mathrm{GtH}$ levels in spite of the depletion of other catecholamines. However, other effects on the reproductive process could be affected by total catecholamines depletion, and this should be evaluated in further studies.

These findings suggest that reserpine can be an effective treatment to induce spermatogenesis in juvenile carps, as well as spermiation and ovulation in mature carps, providing 


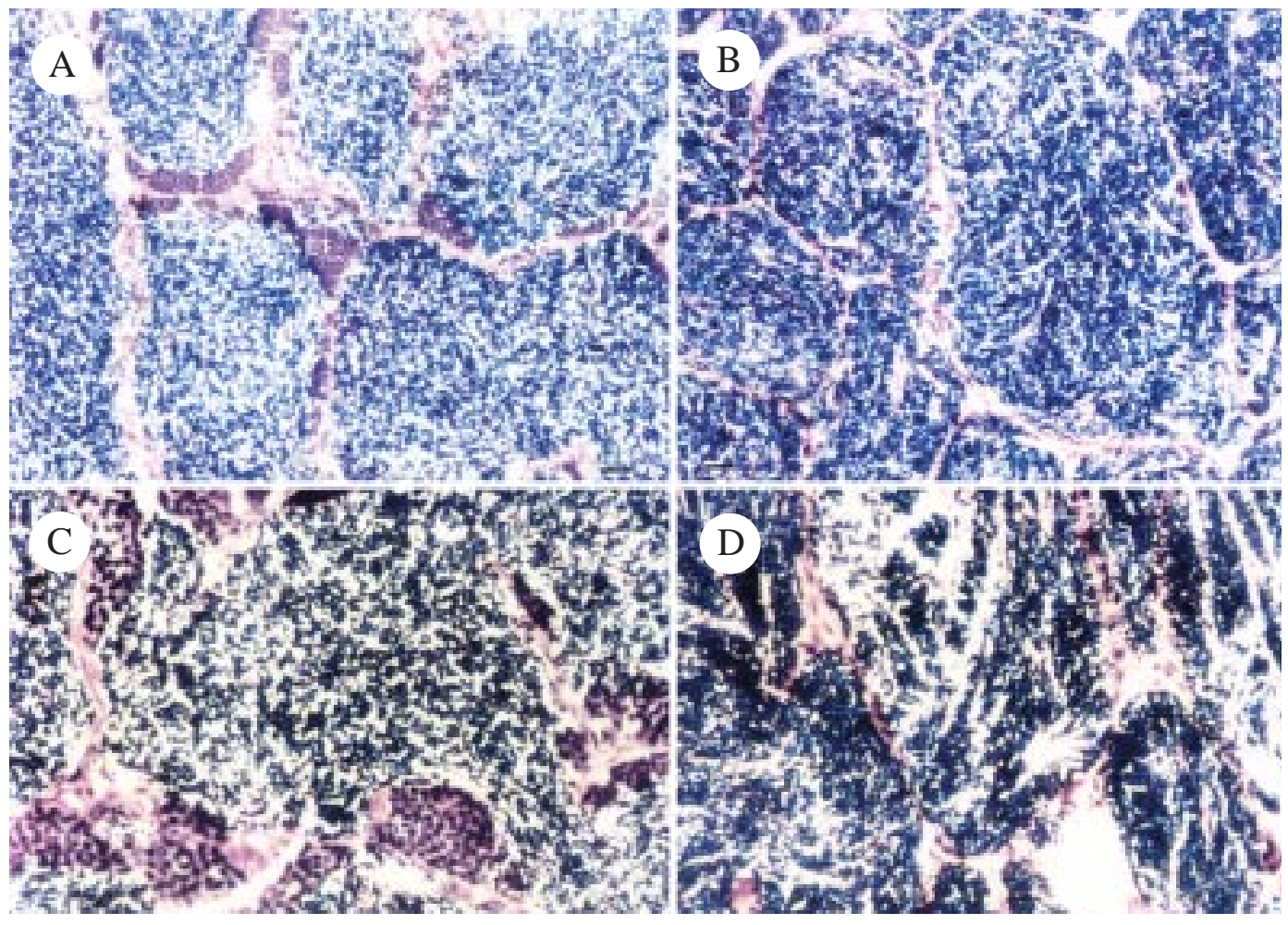

Fig. 2. Sections of testis. A) Control group. Note the presence of primary spermatocytes (E1). Bar scale $25 \mu \mathrm{m}$. B) Control group. The presence of primary spermatocytes in detail from A). Bar scale $50 \mu \mathrm{m}$. C) Group injected with $1.0 \mathrm{mg}$ of reserpine. Spermatozoa (EZ) are noted. Bar scale $25 \mu \mathrm{m}$. D) Group injected with $1.0 \mathrm{mg}$ of reserpine. Spermatozoa (EZ) are noted. Bar scale $50 \mu \mathrm{m}$.

an alternative tool for induced reproduction in fish culture.

\section{RESUMEN}

La secreción de gonadotropinas (GtHs) en pez dorado y carpas, es estimulada por la hormona liberadora de gonadotropinas $(\mathrm{GnRH})$ e inhibida por la dopamina. Trabajos previos con antidopaminérgicos demostraron ser efectivos para estimular la espermiación y ovulación, en varias especies de teleósteos. La reserpina, una sustancia que desaparece catecolaminas, se ha probado con éxito para estimular la espermiación en la carpa común. En este trabajo, reportamos los efectos de la reserpina en el número y volúmen de células gonadotropas en la carpa común. Se aplicaron ocho inyecciones de reserpina a dosis de $0.5,1.0$, y $1.5 \mathrm{mg} / \mathrm{ml} / \mathrm{kg}$ de peso corporal, a intervalos de 48 horas entre cada inyección. Con la dosis de 0.5 $\mathrm{mg} / \mathrm{ml} / \mathrm{kg}$, se encontró un aumento en el número de gonadotrofas de $382 \%$ y de $123 \%$ en el volumen, en comparación con los controles. La dosis de $1.0 \mathrm{mg} / \mathrm{ml} / \mathrm{kg}$ presentó un aumento de $704 \%$ en el número de células y de $152 \%$ en el volumen celular. Con $1.5 \mathrm{mg} / \mathrm{ml} / \mathrm{kg}$ se causó que las gonadotrofas aumentarán $171 \%$ en número y $106 \%$ en volumen. En general, las gónadas de los grupos experimentales presentaron estadios más avanzados de espermatogénesis. Nuestros resultados demuestran que ocho aplicaciones de reserpina provocan el incremento, tanto del número como del volumen, de células gonadotropas.

\section{REFERENCES}

Billard, R., K. Alagarswami \& R.E. Peter. 1983. Potentialisation par le pimozide des effects du LHRH-A sur la secretion gonadotrope hypophysiare, I'ovulation et la spermiation chez la Carpe commune (Cyprinus carpio). C. R. Acad. Sci., Paris Ser. III 296: 181-184. 
Chang, J.P. \& R.E. Peter. 1983. Effects of dopamine on gonadotropin release in female goldfish Carassius auratus. Neuroendocrinology 36: 351-357.

Chang, J.P., A.F. Cook \& R.E. Peter. 1983. Influences of catecholamines on gonadotropin secretion in goldfish Carassius auratus. Gen. Comp. Endocrinol. 49: 22-31.

Chang, J.P., D.S. MacKenzie, D.R. Gould \& R.E. Peter. 1984a. Effects of dopamine and norepinephrine on in vitro spontaneous and gonadotropin-releasing hormone-induced gonadotropin release by dispersed cells or fragments of the goldfish pituitary. Life Sci. 35: 2027-2033.

Chang, J.P., R.E. Peter, C.S. Nahorniak, \& M. Sokolowska. 1984b. Effects of catecholamines agonists and antagonists on serum gonadotropin concentrations and ovulation in goldfish: Evidence for specificity of dopamine inhibition of gonadotropin secretion. Gen. Comp. Endocrinol. 55: 351-360.

Chang, J.P., R.M. Jobin \& A.O.L. Wong. 1993. Intracellular mechanisms mediating gonadotropin and growth hormone release in goldfish, Carassius auratus. Fish. Physiol. Biochem. 11: 25-33.

Jafri, S.I.H. 1979. Combined stain for fish pituitary. Stain Technol. 54: 93-95.

Lin, H.R., J.Y. Liang, G.Y. Li, L.Z. Lu, Y.J. Zhou, G. Van Der Kraak \& R.E. Peter. 1985. The effects of LHRH analogue and drugs which block the effects of dopamine on gonadotropin secretion and ovulation in fish cultured in China, pp. 139-150. In J. Marcel Billard (ed.). Aquaculture of Cyprinids. INRA. Paris, France.
Lin, H.R., C. Peng, G. Van Der Kraak, R.E. Peter \& B. Breton. 1986. Effects of (D-Ala6, Pro9-NEt)-LRH and catecholaminergic drugs on gonadotropin secretion and ovulation in the Chinese loach (Paramisgurnus dabryanus). Gen. Comp. Endocrinol. 64: 389-395.

Luna, L.G. 1968. Manual of histologic staining methods of the forces Institute of Pathology. McGraw-Hill, New York. $258 \mathrm{p}$.

Peter, R.E., J.P. Chang, C.S. Nahorniak, R.J. Omeljaniuk, M. Sokolowska, S.H. Shih, \& R. Billard. 1986. Interactions of catecholamines and GnRH in regulation of gonadotropin secretion in teleost fish. Recent Prog. Hormone Res. 42: 513-548.

Siegel, S. 1994. Estadística no paramétrica. Trillas. México, D.F. pp. 143-224.

Sokolowska, M., R.E. Peter, C.S. Nahorniak, C.H. Pan, J.P. Chang, L.W. Crim \& C. Weil. 1985. The effect of different doses of pimozide and (D-Ala 6, Pro 9-N ethylamide)-LHRH (LHRH-A) on gonadotropin release and ovulation in female goldfish. Can. J. Zool. 63: 1252-1256.

Sokolowska, M., T. Mikolajczyk, P. Epler, R.E. Peter, W. Piotrowski \& K. Bleniarz. 1988. The effects of reserpine and LHRH or salmon GnRH analogues on gonadotropin release, ovulation and spermiation in common carp Cyprinus carpio. Reprod. Nutr. Develop. 28: 889-897.

Sturm, de L., M.G. 1978. Aspects of the biology of Scombermorus maculatas (Mitchill) in Trinidad. J. Fish Biol. 13: 155-172. 